\title{
Antibacterial Activity of Nanoemulsions Based on Essential Oils Compounds Against Species of Xanthomonas that Cause Citrus Canker
}

\author{
Gulherme da Cruz Silva ${ }^{1}$, Josemar Golçalves de Oliveira Filho ${ }^{2, *}$, \\ Marilene de Mori Morselli Ribeiro ${ }^{3 \text { (D) }}$, Clovis Wesley Oliveira de Souza ${ }^{4}$ (D), Marcos David Ferreira 5 (iD
}

1 Department of Biotechnology, Federal University of São Carlos, São Carlos, Brazil; guilhermedcsilva@gmail.com (G.C.S.);

2 São Paulo State University (UNESP), School of Pharmaceutical Sciences, Araraquara; josemar.gooliver@gmail.com (J.G.O.F.);

3 Tanquímica Indústria e Comércio Ltda, Laranjal Paulista, Brazil; marilene@qpgquimica.com.br (M.M.M.R.);

4 Department of Morphology and Patology, Federal University of São Carlos, São Carlos, Brazil; clovis@ufscar.br (C.W.O.S.);

5 Brazilian Agricultural Research Corporation, Embrapa Instrumentação, São Carlos, Brazil; marcos.david@embrapa.br (M.D.F.);

* Correspondence: josemar.gooliver@gmail.com (J.G.O.F.);

Scopus Author ID 57205514981

Received: 6.04.2021; Revised: 10.05.2021; Accepted: 14.05.2021; Published: 10.06.2021

\begin{abstract}
Citrus canker is a bacterial disease that affects citrus crops, caused by microorganisms of the genus Xanthomonas responsible for great damage to citrus production. In this work, the antimicrobial effect of nanoemulsions based on the major compounds of essential oils (EOs) eugenol, thymol, geraniol and menthone were investigated against two strains of Xanthomonas that cause citrus canker (Xac and XauB). Nanoemulsions were produced for each compound using two different stirring speeds (7,000 and 12,000 rpm). All nanoemulsions underwent analysis to characterize particle sizes and stability. Thymol nanoemulsions had the smallest particle sizes (59.8 to $73.9 \mathrm{~nm})$ and the highest stability and also showed the ability to inhibit the development of both strains of bacteria, with minimum inhibitory concentrations (MIC) of $0.03 \%(\mathrm{v} / \mathrm{v})$, along with eugenol $(0.03 \%(\mathrm{v} / \mathrm{v})$ for Xac and $0.02 \%$ $(\mathrm{v} / \mathrm{v})$ for XauB) and geraniol nanoemulsions $(0.06 \%$ (v/v) for both bacteria). Thymol was the compound with the highest minimum bactericidal concentrations (MBC), with values of $0.03 \%(\mathrm{v} / \mathrm{v})$ for both bacterial strains. Eugenol showed MBC only against XauB, at a concentration of $0.03 \%$ (v/v). Geraniol did not show bactericidal activity, suggesting a bacteriostatic action of this compound with the tested microorganisms. In general, the antimicrobial activity of the nanoemulsions was increased with increased agitation speed, particle reduction and greater stability. Therefore, nanoemulsification can be an alternative to applying the antimicrobial activity of natural compounds in the control of citrus canker.
\end{abstract}

Keywords: citrus canker; Xanthomonas citri subsp. citri; Xanthomonas fuscans subsp. aurantifolii type B; eugenol; thymol.

(C) 2021 by the authors. This article is an open-access article distributed under the terms and conditions of the Creative Commons Attribution (CC BY) license (https://creativecommons.org/licenses/by/4.0/).

\section{Introduction}

Citriculture is one of the most important agribusiness sectors worldwide, being a decisive branch of the economy of several countries and an important machine for generating jobs [1]. This phenomenon happens because, in addition to their consumption in nature, citrus fruits are also consumed through their processed products, such as juices and sweets [2]. In the 
last decade, several diseases have been responsible for causing numerous losses to the citrus industry, such as citrus variegated chlorosis (CVC), huanglongbing or greening (HLB), sudden citrus death (CSD) and citrus canker [3-5].

Citrus canker, in particular, is a disease with a high impact on the global citrus industry, which can cause defoliation and premature fall of infected fruits [6]. It is caused by Gramnegative bacteria species of genus Xanthomonas [7], which can cause three main types of the disease: Canker A, caused by X. citri subsp. citri (Xac); Canker B, caused by X. fuscans subsp. aurantifolii type B (XauB); and Canker C, caused by X. fuscans subsp. aurantifolii type C $(\mathrm{XauC})$. The host species may differ for each type, but the symptoms presented by the infected fruits are, in general, similar $[8,6]$.

There are still no curative methods for the treatment of citrus canker [9-10]. Prevention for places with no record of the disease is carried out by eradicating infected plants [11]. Where citrus canker is endemic, copper-based antimicrobial compounds are sprayed to control the disease [12]. However, in addition to not being a totally efficient measure, the use of copper agrochemicals can cause damage to human health and the environment in the long term [13]. There are also records of Xanthomonas species resistant to copper-based antibacterials [14-15].

In order to prevent major damage to agriculture crops caused by phytopathogenic microorganisms, the use of techniques that take advantage of natural and biodegradable alternatives has been extensively studied in recent years [16-17]. An example of this is the use of essential oils (EOs) and other plant extracts, which can provide antimicrobial activity due to their vast bioactive compounds $[18,16]$. It has been reported that the use of these compounds isolated instead of the entire essential oils increases their action as potential antimicrobial agents [19]. Thymol (the major compound of thyme oil), eugenol (abundant in clove oil), geraniol (found in palmarosa oil) and menthone (a component of the essential oil of peppermint) are only a few of the natural compounds from EOs known to possess antimicrobial properties [20-21].

To be applied to fruits, however, it is necessary to create emulsions of EO's components in order to guarantee their function [22]. In this sense, nanotechnology is a possible ally to enhance the antimicrobial effects of natural compounds [22-23]. When being nanoemulsified, their physical-chemical characteristics are better preserved and their dispersion across biological membranes is greater [24].

Thus, to satisfy the increasing demands of consumers for sustainability and help agriculture have a less negative impact on the environment, alternatives to the overuse of agrochemicals must be found. Therefore, the present study aimed at the association of thymol, eugenol, geraniol and menthone with nanotechnology to investigate their antibacterial potential in the control of citrus canker.

\section{Materials and Methods}

\subsection{Materials.}

Thymol (lot T0501), eugenol (lot E51791), geraniol (lot 163333) and menthone (lot 95401) were obtained from Sigma-Aldrich Brasil Ltda. The bacterial strains used in the study were Xac strain 306 [25] and XauB strain ICPB11122 [8]. Both bacteria were gently given by the Laboratory of Applied Biochemistry and Molecular Biology (LBBMM) from the Department of Genetics and Evolution of Federal University of São Carlos (UFSCar), São 
Paulo, Brazil. Tween 80 (ethoxylated sorbitan monooleate) was obtained from Labsynth Brasil Ltda.

\subsection{Inoculum preparation.}

The inoculum of both bacteria was prepared using Petri dishes with solid Luria-Bertani (LB) medium incubated for 3 days at $28^{\circ} \mathrm{C}$. Approximately two colonies isolated from each microorganism were collected and transferred to $50 \mathrm{~mL}$ of sterile $\mathrm{LB}$ liquid culture medium, kept under agitation at $180 \mathrm{rpm}$ and $28^{\circ} \mathrm{C}$ for 24 hours. After this period, an aliquot of $1 \mathrm{~mL}$ of each culture was collected and read in a spectrophotometer at a wavelength of $625 \mathrm{~nm}$. The absorbance reading was compared with the reading of a solution corresponding to the 0.5 points on the McFarland Scale (approximately $1.5 \times 10^{8} \mathrm{CFU} / \mathrm{mL}$ ). Then, dilutions were made in liquid LB to obtain a standardized inoculum for each bacterium with a 2 x $105 \mathrm{CFU} / \mathrm{mL}$ concentration. The concentration was confirmed by plating $100 \mu \mathrm{L}$ of the inoculum in a solid LB medium with a sterile Drigalski loop [26-27].

\subsection{Nanoemulsions preparation and characterization.}

Each compound was diluted in sterile distilled water in order to obtain the final concentrations of $2 \%(\mathrm{v} / \mathrm{v})$ for geraniol, $2 \%(\mathrm{w} / \mathrm{v})$ for thymol and $1 \%(\mathrm{v} / \mathrm{v})$ for eugenol and menthone. Tween $80(0.05 \% \mathrm{v} / \mathrm{v})$ were added as an emulsifying agent [28].

Each sample of thymol (NET), eugenol (NEE), geraniol (NEG) and menthone (NEM) was stirred for $4 \mathrm{~min}$ in Ultra-Turrax at two different speeds: 7,000 and 12,000 rpm, at room temperature, totaling 8 treatments.

The nanoemulsions were characterized with Zetasizer Nano ZS, from Malvern Panalytical. Particle size (in nm) and the polydispersity index (PDI) were measured. Three aliquots were collected from each sample and read at 0 and $24 \mathrm{~h}$ to verify the stability of the nanoemulsions. Between readings, all samples were kept refrigerated at $4{ }^{\circ} \mathrm{C}$ in a container with a barrier to the entry of light [29].

\subsection{Minimum inhibitory concentration (MIC) assay.}

In a sterile 96-well plate, $50 \mu \mathrm{L}$ of liquid LB medium was deposited in each well, followed by the addition of $50 \mu \mathrm{L}$ of bacterial inoculum at $2 \times 10^{5} \mathrm{CFU} / \mathrm{mL}$, in order to obtain a final concentration of $10^{5} \mathrm{CFU} / \mathrm{mL}$ in all wells, with a final volume of $100 \mu \mathrm{L}$. The two bacteria were tested separately. Then, in the wells of the first row, each nanoemulsion was added in the volume of $100 \mu \mathrm{L}$, reducing its initial concentration by half. Then, a serial dilution was performed, transferring $100 \mu \mathrm{L}$ from the initial well to the subsequent wells in the vertical direction of the plate. Thus, all NEG and NET treatments were tested at the final concentrations of $1,0.5,0.25,0.13,0.06,0.03,0.02$ and $0.01 \%(\mathrm{v} / \mathrm{v})$, and the NEE and NEM treatments received the final concentrations of $0.5,0.25,0.13,0.06,0.03,0.02,0.01$ and $0.004 \%(\mathrm{v} / \mathrm{v})$. All nanoemulsions were tested in triplicate. Controls were also performed with the addition of distilled water at $1 \%(\mathrm{v} / \mathrm{v})$ and Tween 80 at $0.05 \%(\mathrm{v} / \mathrm{v})$. The plates were incubated, without shaking, at $28^{\circ} \mathrm{C}$ for $24 \mathrm{~h}[30]$.

After the incubation period, $30 \mu \mathrm{L}$ of a $0.1 \%(\mathrm{w} / \mathrm{v})$ solution of the 2,3,5triphenyltetrazolic chloride reagent was added to each well of the microplates, returning them to the incubator for $30 \mathrm{~min}$. This reagent is a dye that interacts with enzymes involved in cellular respiration to detect the wells in which there is still metabolic activity (reddish color). 
Thus, the MIC was defined as the lowest concentration in which no color was visible in the corresponding well [31].

\subsection{Minimum bactericidal concentration (MBC) assay.}

The minimum bactericidal concentration was investigated by plating in solid LB medium $100 \mu \mathrm{L}$ for each repetition of the wells in which MIC was defined and subsequent. The spreading of the aliquot was done using a sterile Drigalski loop. Negative controls were also plated. All plates were incubated at $28^{\circ} \mathrm{C}$ for $24 \mathrm{~h}$. MBC was defined as the lowest sample concentration in which there was no visible microbial growth in the Petri dish [30].

\subsection{Statistical analysis.}

Data from nanoemulsions characterization were first analyzed using two-way ANOVA analysis of variance in triplicate. When necessary, the differences between treatments were determined using the Tukey Test $(\mathrm{p}<0.05)$ for the data referring to the agitation speeds within each treatment and the Student T-Test $(\mathrm{p}<0.05)$ for comparison between the readings at 0 and 24h.

\section{Results and Discussion}

\subsection{Characterization of nanoemulsions.}

The average values of the characterizations of the nanoemulsions are described in Table 1. Most of them were able to decrease the size of the particles (z-average) from the first stirring speed $(7,000 \mathrm{rpm})$ to the second $(12,000 \mathrm{rpm})$. This result coincides with the data already described in the literature. Otani et al. [29] used these same speeds to produce cinnamaldehyde nanoemulsions and obtained values more than twice as low in the rotation of $12,000 \mathrm{rpm}$ compared to 7,000 rpm. This happens due to the fact that processes that demand high energy create deforming forces that overcome the pressure of Laplace and break the particles into smaller sizes [31].

Table 1. Characterization results of eugenol (NEE), geraniol (NEG), thymol (NET) and menthone (NEM) nanoemulsions. The sizes (z-average, in $\mathrm{nm}$ ) and the polydispersion indices (PDI) of the particles are shown for each stirring speed used. Readings were done 0 and 24 hours after sample preparation.

\begin{tabular}{|c|c|c|c|c|c|c|c|c|}
\hline \multirow{4}{*}{ Sample } & \multicolumn{8}{|c|}{ Stirring speed (rpm) } \\
\hline & \multicolumn{4}{|c|}{7.000} & \multicolumn{4}{|c|}{12.000} \\
\hline & \multicolumn{2}{|c|}{$\mathbf{O h}$} & \multicolumn{2}{|c|}{$24 \mathrm{~h}$} & \multicolumn{2}{|c|}{$\mathbf{O h}$} & \multicolumn{2}{|c|}{$24 \mathrm{~h}$} \\
\hline & $\begin{array}{c}\text { z-average } \\
\text { (nm) }\end{array}$ & PDI & $\begin{array}{c}\text { z-average } \\
\text { (nm) }\end{array}$ & PDI & $\begin{array}{c}\text { z-average } \\
\text { (nm) }\end{array}$ & PDI & $\begin{array}{c}\text { z-average } \\
\text { (nm) }\end{array}$ & PDI \\
\hline NEE & $190.2^{\mathrm{aB}}$ & $0.49^{\mathrm{aA}}$ & $270.6^{\mathrm{aA}}$ & $0.90^{\mathrm{aB}}$ & $131.2^{\mathrm{bA}}$ & $0.02^{\mathrm{bA}}$ & $137.5^{\mathrm{bA}}$ & $0.28^{\mathrm{bB}}$ \\
\hline NEG & $98.7^{\mathrm{aB}}$ & $0.17^{\mathrm{aA}}$ & $150.0^{\mathrm{aA}}$ & $0.98^{\mathrm{aB}}$ & $99.4^{\mathrm{aB}}$ & $0.10^{\mathrm{bA}}$ & $156.2^{\mathrm{aA}}$ & $0.13^{\mathrm{bB}}$ \\
\hline NET & $91.1^{\mathrm{bA}}$ & $0.06^{\mathrm{aA}}$ & $91.7^{\mathrm{aA}}$ & $0.58^{\mathrm{aA}}$ & $59.8^{\mathrm{cA}}$ & $0.26^{\mathrm{bA}}$ & $73.9^{\mathrm{bA}}$ & $0.14^{\mathrm{bB}}$ \\
\hline NEM & $299.6^{\mathrm{bA}}$ & $0.86^{\mathrm{bA}}$ & $612.7^{\mathrm{bB}}$ & $0.55^{\mathrm{bA}}$ & $169.2^{\mathrm{cA}}$ & $0.94^{\mathrm{aA}}$ & $325.4^{\mathrm{bB}}$ & $0.74^{\mathrm{aB}}$ \\
\hline
\end{tabular}

${ }^{\text {a-c }}$ Different letters indicate statistically relevant differences between stirring speeds within each treatment using the Tukey test $(\mathrm{p}<0.05)$

A-B Different letters indicate statistically relevant differences between the times 0 and $24 \mathrm{~h}$ by the Student T-Test $(\mathrm{p}<0.05)$

The treatments with geraniol were the only ones that did not show a relevant reduction in the size of the particles, without any statistically significant difference between the averages 
of the values presented for each of the two agitation speeds, which varied from 98.7 to 156.2 $\mathrm{nm}$. This may be due to multiple factors, such as the need for a longer stirring time or the addition of different surfactants. Previous studies have shown that a longer stirring time can produce geraniol nanoemulsions with particle sizes of $68 \mathrm{~nm}$ in diameter [32].

In addition, the particle size and stability of an emulsion are related to the choice of the emulsifier, both because of its composition in relation to the active component and because of its hydrophilic-lipophilic balance (HLB) value, which represents the size and strength of the hydrophilic and lipophilic portions of the emulsifier molecule [33]. Therefore, the use of emulsifiers with HLB values different than that presented by Tween 80 (HLB 15) may be an alternative for the production of geraniol nanoemulsions with reduced particle sizes.

The smallest particle sizes were obtained at the second speed $(12,000 \mathrm{rpm})$, ranging from 59.8 to $73.9 \mathrm{~nm}$ for NET treatments. These were also the treatments with the most stable $\mathrm{z}$-average values, with no significant differences after $24 \mathrm{~h}$. This greater stability is directly related to the size of the particles since the lower the $\mathrm{z}$-average values in a nanoemulsion, the more stable it shows over time [34]. A study by Su \& Zhong [35] performed a test in which nanoemulsions containing $2 \%$ thymol (w/v) were produced by stirring in Ultra-Turrax for 2 minutes at 10,000 rpm, obtaining z-average values similar to that observed in the present work (from 38.67 to $58.08 \mathrm{~nm}$ ).

The largest particle diameters were those of NEE $(270.6 \mathrm{~nm})$ and NEM $(621.7 \mathrm{~nm})$ treatments, at 7,000 rpm. These were also the most unstable samples after $24 \mathrm{~h}$, with statistically significant differences in values. This happens because there is a correlation between the particle size and the stability of the nanoemulsion. When the particles are larger, there are chances that sedimentation will occur during storage, along with coalescence [34].

Multiple studies with characterizations of nanoemulsions containing eugenol demonstrated results similar to the z-average values found for NEE. Hu et al. [36] obtained particles of $103.6 \mathrm{~nm}$ when producing nanoemulsions containing $1.25 \%$ eugenol (v/v) using different techniques and natural emulsifiers. In another study, Wang \& Zhang [37] produced eugenol nanoemulsions ( $1 \% \mathrm{v} / \mathrm{v})$ using different stirring methods, reaching $\mathrm{z}$-average values of up to $158.4 \mathrm{~nm}$ in diameter. There are few reports in the literature about menthone-based nanoemulsions. However, a study by Liang et al. [38] used peppermint essential oil (rich in menthone) to produce nanoemulsions by stirring in Ultra-Turrax for 1 minute at 24,000 rpm, obtaining nanoparticles in the $200 \mathrm{~nm}$ diameter range, which corresponds to the values found in this study for the treatment of NEM. Yet, all results demonstrate that treatments with eugenol (NEE) and menthone (NEM) are particularly unstable, making its long-term use impracticable. For this to be corrected, further tests are needed to include other emulsifying agents and validate different methods of producing nanoemulsions.

The polydispersion index (PDI) showed a great distinction between the studied nanoemulsions. The statistical analysis pointed out relevant differences between the data obtained in the reading of 0 and $24 \mathrm{~h}$. This is related to the fact that the particles tend to agglomerate and form precipitates, which modifies the initial homogeneity of the sample [34]. In general, the PDI has a behavior dependent on the stability of the sample and the size of the particles: the highest values of PDI obtained were from the NEG (0.98) and NEM (0.94) treatments, which also showed high values of z-average. On the other hand, the one who presented low values of z-average also had smaller and less variable PDIs: NET (0.06). These results coincided with what was observed in a study by Pongsumpun et al. [39], in which the comparison of two methods for obtaining cinnamon essential oil nanoemulsions revealed that 
the methodology responsible for obtaining the smallest particle diameters also produced the lowest PDI values. The only treatment that did not follow this pattern was NEE, which also demonstrated one of the lowest PDI values (0.10), but had relatively high z-average values. This may indicate that the surfactant used had a more stable interaction with eugenol than with the other treatments in which the z-average values were also high.

\subsection{Minimum inhibitory concentration (MIC) assay.}

The results for the tests of minimum inhibitory concentration (MIC) with Xac and XauB are described in Table 2. The thymol nanoemulsions (NET) were the ones that obtained the best result, with MIC of $0.03 \%$ for Xac in the sample with rotation of 12,000 rpm, and MIC of $0.02 \%$ for XauB also at $12,000 \mathrm{rpm}$.

Table 2. Results for the minimum inhibitory concentration (MIC) assay with Xanthomonas citri subsp. citri (Xac) and Xanthomonas fuscans subsp. aurantifolii (XauB). The concentrations of eugenol (NEE), geraniol (NEG), thymol (NET), menthone (NEM) present in their respective nanoemulsion are described in percentage $(\mathrm{v} / \mathrm{v})$, in the two stirring speeds used (7,000 and 12,000 rpm).

\begin{tabular}{|c|c|c|c|c|}
\hline \multirow{3}{*}{ Sample } & \multicolumn{4}{|c|}{ Stirring speed (rpm) } \\
\hline & \multicolumn{2}{|c|}{ Xac } & \multicolumn{2}{|c|}{ XauB } \\
\hline & 7.000 & 12.000 & 7.000 & 12.000 \\
\hline NEE & $0.06 \%$ & $0.03 \%$ & $0.13 \%$ & $0.03 \%$ \\
\hline NEG & $0.06 \%$ & $0.06 \%$ & $0.06 \%$ & $0.06 \%$ \\
\hline NET & $0.06 \%$ & $0.03 \%$ & $0.13 \%$ & $0.02 \%$ \\
\hline NEM & $>0.5 \%$ & $>0.5 \%$ & $>0.5 \%$ & $>0.5 \%$ \\
\hline Negative control & $*$ & $*$ & $*$ & $*$ \\
\hline Tween 80 & $*$ & $*$ & $*$ & $*$ \\
\hline
\end{tabular}

* There was no MIC in the concentrations tested.

These values coincide with a study by Nostro et al. [40] where the antimicrobial activity of thymol, carvacrol and oregano essential oil was tested against several strains of Staphylococcus aureus, obtaining MIC values between $0.03 \%$ and $0.06 \%$ (v/v). Kotan et al. [41], when evaluating the activity of multiple natural compounds against Xanthomonas axonopodis pv. vesicatoria, also obtained the lowest MIC in the treatment using thymol. In addition, some studies involving the use of essential oils having thymol as a major compound have already shown an antagonistic behavior of this compound against species of the genus Xanthomonas [42-43].

The high antibacterial activity of thymol is well described in the literature [44]. Banti et al. [45] tested the activity of essential oils containing thymol as the main constituent, finding antibacterial action even against strains resistant to antibiotics. Although the action of thymol against Xac and XauB has not yet been explored in the literature, the results of this study are consistent with what has been reported for other species of the genus Xanthomonas [42]. Da Silva et al. [43], when evaluating the cell viability of Xanthomonas campestris pv. campestris when exposed to thymol, reported damage to the cytoplasmic membrane that is probably related to the antibacterial mechanism of this compound.

The second best treatment was NEE, with MIC of $0.03 \%(\mathrm{v} / \mathrm{v})$ at the rotation of 12,000 rpm for both bacteria tested. Marchese et al. [46] compared the activity of eugenol against several bacterial strains, finding MICs from 0.1 to $0.01 \%$ (v/v) against Gram-negative bacteria, which coincides with the results of the present study. Sauer et al. [47], when testing the antiXac activity of Ocimum gratissimum L. essential oil (containing $42.7 \%$ eugenol), obtained MIC 
of $0.43 \mu \mathrm{L} / \mathrm{mL}$. Considering the percentage of eugenol present in the oil, it is expected that the isolated compound has a lower MIC against Xac, as occurred in this work.

Geraniol treatments (NEG) showed the least activity, with MIC of $0.06 \%$ (v/v) in all rotations for Xac and XauB. Reichling et al. (2006) has already reported the antibacterial activity of geraniol in similar concentrations, with MIC of $0.05 \%(\mathrm{v} / \mathrm{v})$ for Escherichia coli and $0.06 \%$ (v/v) for Staphylococcus aureus. Mirzaei-Najafgholi et al. [48] demonstrated that geraniol is able to inhibit the development of Xac at a concentration of $0.09 \%(\mathrm{v} / \mathrm{v})$. As with eugenol, there have been no reports of anti-XauB tests using geraniol.

With the exception of geraniol treatments, all other nanoemulsions had an increase in the antimicrobial activity of the rotation from 7,000 rpm to $12,000 \mathrm{rpm}$. This phenomenon is consistent with what is described in the literature. Mutlu-Ingok et al. [49], when performing tests of antimicrobial activity with nanoemulsions of essential oils with different values of zaverage, obtained an inverse relationship between the average size of the suspended particles and the antibacterial action. That is, the lower the z-average value, the greater the activity of the nanoemulsion. The same was reported by Otani et al. [29] in trials involving cinnamaldehyde nanoemulsions against $E$. coli, S. aureus, L. monocytogenes and S. enterica. In this work, treatments with smaller particle sizes showed the greatest inhibition halos.

This happens because the nanoparticles increase the sample's contact surface with the microorganism, improving the accessibility of bioactive compounds and their ability to enter cell membranes [34]. There are studies, however, that report a low influence of the size of the particles on the antimicrobial action, which is more susceptible to the components of the nanoemulsion and its compositions. For this reason, nanoemulsions with different $\mathrm{z}$-average can have similar antimicrobial activities [50-51]. There are already some studies proving the effectiveness of nanoemulsions against species of the genus Xanthomonas, including using thymol as a bioactive component [52].

There was no MIC for NEM treatments. Menthone was tested at a reduced concentration, which may explain the lack of activity since its antimicrobial action has already been reported in concentrations above $2 \%$ (v/v) [53].

Among the three compounds that presented MIC, the treatments with thymol (NET) were more efficient against XauB than Xac, with concentrations of $0.03 \%$ (v/v) for Xac and $0.02 \%(\mathrm{v} / \mathrm{v})$ for $\mathrm{XauB}$ at the same speed $(12,000 \mathrm{rpm})$. Although not very significant, this difference may indicate that this compound acts differently for each species.

Studies have shown that Xac and XauB have differences in the protein composition of the periplasm region that give them different spectra of hosts and levels of pathogenicity, with Xac being a more virulent species than XauB [54]. Therefore, such distinctions in bacterial morphology may be related to the membrane permeability mechanisms through which thymol acts, allowing it to interact closer with XauB than Xac.

\subsection{Minimum bactericidal concentration (MBC) assay.}

The results for the tests of minimum bactericidal concentration (MBC) with Xac and $\mathrm{XauB}$ are described in Table 3. As with the MIC values, the treatments that presented the most MBCs were the nanoemulsions containing thymol (NET), being $0.03 \%$ for both bacteria at $12,000 \mathrm{rpm}$ and there was no MBC for the rotation of 7,000 rpm. 
Table 3. Results for the test to assess the minimum bactericidal concentration (MBC) with Xanthomonas citri subsp. citri (Xac) and Xanthomonas fuscans subsp. aurantifolii (XauB). The concentrations of eugenol (NEE), geraniol (NEG) and thymol (NET) present in their respective nanoemulsion are described in percentage (v/v), in the two stirring speeds used (7,000 and 12,000 rpm).

\begin{tabular}{c|c|c|c|c}
\multirow{2}{*}{ Sample } & \multicolumn{4}{|c}{ Stirring speed (rpm) } \\
\cline { 2 - 5 } & \multicolumn{3}{|c}{ Xac } & \multicolumn{2}{c}{ XauB } \\
\cline { 2 - 5 } & $\mathbf{7 . 0 0 0}$ & $\mathbf{1 2 . 0 0 0}$ & $\mathbf{7 . 0 0 0}$ & $\mathbf{1 2 . 0 0 0}$ \\
\hline NEE & $>0.5 \%$ & $>0.5 \%$ & $>0.5 \%$ & $0.03 \%$ \\
\hline NEG & $>1 \%$ & $>1 \%$ & $>1 \%$ & $>1 \%$ \\
\hline NET & $>1 \%$ & $0.03 \%$ & $>1 \%$ & $0.03 \%$ \\
\hline Negative control & $*$ & $*$ & $*$ & $*$
\end{tabular}

* There was no MBC in the concentrations tested.

These results reflect that thymol inhibitory activity is related to bactericidal activity, since both MIC and MBC values had equal or very close concentrations. Nostro et al. [40], when evaluating the bactericidal activity of thymol against species of the Staphylococcus genus, obtained similar MBC values, ranging from 0.031 to $0.125 \%$ (v/v). However, the bactericidal action only occurred in treatments where the $\mathrm{z}$-average was lower in the present study. This coincides with what was reported in a study by Sarwar et al. [55], where the evaluation of the bactericidal activity of chitosan nanoparticles against different Gram-positive and Gram-negative bacteria demonstrated lower MBC results for treatments with smaller particle sizes.

In the treatments with eugenol (NEE), only the bacterium XauB was susceptible, presenting the MBC of $0.03 \%$ in the rotation of $12,000 \mathrm{rpm}$. This difference in behavior between the two species is an expected phenomenon since there are considerable distinctions in each bacterium's morphology that can influence how the bioactive compound interacts with the cell membrane. Zandonadi et al. [54], when evaluating the periplasmic proteome of different strains of Xanthomonas that cause citrus canker, observed that there are distinctions in the proteins present in this region. Thus, even though the MIC values were the same, the bactericidal activity of eugenol appears to have mechanisms that are more effective against XauB than Xac, although Xac is, in general, more virulent.

There was no bactericidal action in the other rotations, nor for the treatments with geraniol (NEG). This absence of activity may indicate that the interaction of the compounds with the bacteria occurs through bacteriostatic mechanisms. That is, even though the MIC values demonstrate an inhibitory potential, only concentrations above those that have been tested may actually be able to kill the bacterial cells. Bajpai et al. [56], when testing the essential oil and extracts from Cleistocalyx operculatus against Xanthomonas species, found MBC concentrations above the values presented by the MIC assay. The different mechanisms through which the bioactive compound interacts with the microorganism can also influence the bactericidal action. Silva et al. [57], when evaluating the antimicrobial potential of different essential oils against $S$. aureus and $E$. coli, obtained MIC concentrations that could or might not be bactericidal, depending on the species of bacteria.

\section{Conclusions}

The antimicrobial activity was shown to be greater as the particle size of the nanoemulsions decreased. Nanoemulsions with a lower z-average are more stable and enhance the bioactivity of natural compounds of EOs. Among the studied compounds, those that showed the best efficiency against the tested bacteria were thymol and eugenol. Although it also 
showed low concentrations of MIC, geraniol did not obtain MBC results, which demands the need for new tests using higher concentrations of the compound. Most compounds showed bacteriostatic activity, with only thymol and eugenol being able to prevent bacteria development completely. Satisfactory results of bacterial inhibition were obtained in all low concentrations used, which suggests the use of small volumes of these components in possible large-scale applications. Future tests are needed to assess the in vivo toxicity of thymol and eugenol nanoemulsions in citrus fruits and encapsulation studies (spray dryer) for greater protection of the active principle.

\section{Funding}

The authors are thankful for the financial support provided by São Paulo Research Foundation (process 2018/24612-9), Brazilian National Council for Scientific and Technological Development - CNPq (grant\# 407956/2016-6 and Research Productivity Fellowship 310728/2019-3), Empresa Brasileira de Pesquisa Agropecuária (Embrapa), Rede Agronano, and MCTI-SisNano from Brazil.

\section{Acknowledgments}

The authors are thankful to Dr. Marcela Miranda, collaborator of the Empresa Brasileira de Pesquisa Agropecuária (Embrapa), for her contribution to the initial conception of this project, and to professor Maria Teresa Marques Novo Mansur, by the Laboratory of Applied Biochemistry and Molecular Biology (LBBMM), Department of Genetics and Evolution of Federal University of São Carlos (UFSCar), São Paulo, Brazil, for gently giving the bacterial strains used in this study.

\section{Conflicts of Interest}

The authors declare no conflict of interest. The funders had no role in the study's design, in the collection, analyses, or interpretation of data, in the writing of the manuscript, or in the decision to publish the results.

\section{References}

1. Mattos-Jr, D.; Carlos, E.F. The role of the International Society of Citriculture on the world citrus industry. Citrus Research \& Technology 2019, 38, 228-232.

2. Rampersaud, G.C.; Valim, M.F. $100 \%$ citrus juice: Nutritional contribution, dietary benefits, and association with anthropometric measures. Crit. Rev. Food Sci. Nutr. 2017, 57, 129-140, https://doi.org/10.1080/10408398.2013.862611.

3. Lopes, S.A. Scion Substitution: A New Strategy to Control Citrus Variegated Chlorosis Disease. Plant Dis. 2019, 104, 239-245, https://doi.org/10.1094/PDIS-02-19-0302-RE.

4. Sun, L.; Nasrullah; Ke, F.; Nie, Z.; Wang, P.; Xu, J. Citrus Genetic Engineering for Disease Resistance: Past, Present and Future. Int. J. Mol. Sci. 2019, 20, https://doi.org/10.3390/ijms20215256.

5. Matsumura, E.E.; Coletta-Filho, H.D.; Nouri, S.; Falk, B.W.; Nerva, L.; Oliveira, T.S.; Dorta, S.O.; Machado, M.A. Deep Sequencing Analysis of RNAs from Citrus Plants Grown in a Citrus Sudden Death-Affected Area Reveals Diverse Known and Putative Novel Viruses. Viruses 2017, 9, https://doi.org/10.3390/v9040092.

6. Brunings, A.M.; Gabriel, D.W. Xanthomonas citri: breaking the surface. Mol. Plant Pathol. 2003, 4, 141157, https://doi.org/10.1046/j.1364-3703.2003.00163.x.

7. Savietto, A.; Polaquini, C.R.; Kopacz, M.; Scheffers, D.-J.; Marques, B.C.; Regasini, L.O.; Ferreira, H. Antibacterial activity of monoacetylated alkyl gallates against Xanthomonas citri subsp. citri. Arch. Microbiol. 2018, 200, 929-937, https://doi.org/10.1007/s00203-018-1502-6.

8. Moreira, L.M.; Almeida, N.F.; Potnis, N.; Digiampietri, L.A.; Adi, S.S.; Bortolossi, J.C.; da Silva, A.C.; da Silva, A.M.; de Moraes, F.E.; de Oliveira, J.C.; de Souza, R.F.; Facincani, A.P.; Ferraz, A.L.; Ferro, M.I.; Furlan, L.R.; Gimenez, D.F.; Jones, J.B.; Kitajima, E.W.; Laia, M.L.; Leite, R.P.; Nishiyama, M.Y.; Rodrigues Neto, J.; Nociti, L.A.; Norman, D.J.; Ostroski, E.H.; Pereira, H.A.; Staskawicz, B.J.; Tezza, R.I.; 
Ferro, J.A.; Vinatzer, B.A.; Setubal, J.C. Novel insights into the genomic basis of citrus canker based on the genome sequences of two strains of Xanthomonas fuscans subsp. aurantifolii. BMC Genomics 2010, 11, 238, https://doi.org/10.1186/1471-2164-11-238.

9. Silva, I. C.; Regasini, L. O.; Petrônio, M. S.; Silva, D. H. S.; Bolzani, V. S.; Belasque Jr, J..; Sacramento, L. V. S.; Ferreira, H. Antibacterial Activity of Alkyl Gallates against Xanthomonas citri subsp. citri. J. Bacteriol. 2013, 195, 85, https://doi.org/10.1128/JB.01442-12.

10. Soares, J.M.; Tanwir, S.E.; Grosser, J.W.; Dutt, M. Development of genetically modified citrus plants for the control of citrus canker and huanglongbing. Tropical Plant Pathology 2020, 45, 237-250, https://doi.org/10.1007/s40858-020-00362-9

11. Behlau, F.; Barelli, N.L.; Belasque Jr, J. Lessons from a case of successful eradication of citrus canker in a citrus-producing farm in São Paulo State, Brazil. J. Plant Pathol. 2014, 96, 561-568, http://doi.org/10.4454/JPP.V96I3.026.

12. Behlau, F.; Lanza, F.E.; da Silva Scapin, M.; Scandelai, L.H.M.; Silva Junior, G.J. Spray volume and rate based on the tree row volume for a sustainable use of copper in the control of citrus canker. Plant Dis. 2021, 105, 183-192, https://doi.org/10.1094/PDIS-12-19-2673-RE.

13. Daungfu, O.; Youpensuk, S.; Lumyong, S. Endophytic bacteria isolated from citrus plants for biological control of citrus canker in lime plants. Tropical life sciences research 2019, 30, 73, https://doi.org/10.21315/tlsr2019.30.1.5.

14. Richard, D.; Boyer, C.; Vernière, C.; Canteros, B. I.; Lefeuvre, P.; Pruvost, O. Complete Genome Sequences of Six Copper-Resistant Xanthomonas citri pv. citri Strains Causing Asiatic Citrus Canker; Obtained Using Long-Read Technology. Genome Announcements 2017, 5, e00010-00017, https://doi.org/10.1128/genomeA.00010-17.

15. Behlau, F.; Gochez, A.M.; Jones, J.B. Diversity and copper resistance of Xanthomonas affecting citrus. Tropical Plant Pathology 2020, 45, 200-212, https://doi.org/10.1007/s40858-020-00340-1.

16. Oliveira Filho, J.G.d.; da Cruz Silva, G.; de Aguiar, A.C.; Cipriano, L.; de Azeredo, H.M.C.; Bogusz Junior, S.; Ferreira, M.D. Chemical composition and antifungal activity of essential oils and their combinations against Botrytis cinerea in strawberries. Journal of Food Measurement and Characterization 2021, 15, 18151825, https://doi.org/10.1007/s11694-020-00765-x.

17. Raveau, R.; Fontaine, J.; Lounès-Hadj Sahraoui, A. Essential Oils as Potential Alternative Biocontrol Products against Plant Pathogens and Weeds: A Review. Foods 2020, 9, https://doi.org/10.3390/foods9030365.

18. Perdones, A.; Sánchez-González, L.; Chiralt, A.; Vargas, M. Effect of chitosan-lemon essential oil coatings on storage-keeping quality of strawberry. Postharvest Biol. Technol. 2012, 70, 32-41, https://doi.org/10.1016/j.postharvbio.2012.04.002.

19. Freires, I.A.; Denny, C.; Benso, B.; De Alencar, S.M.; Rosalen, P.L. Antibacterial Activity of Essential Oils and Their Isolated Constituents against Cariogenic Bacteria: A Systematic Review. Molecules 2015, 20, https://doi.org/10.3390/molecules20047329.

20. Dal Pozzo, M.; Viégas, J.; Santurio, D.F.; Rossatto, L.; Soares, I.H.; Alves, S.H.; da Costa, M.M. Antimicrobial activities of essential oils extracted from spices against Staphylococcus spp isolated from goat mastitis. Ciência Rural 2011, 41, 667-672, https://doi.org/10.1590/S0103-84782011005000029.

21. Kim, J.M.; Marshall, M.R.; Cornell, J.A.; Iii, J.F.P.; Wei, C.I. Antibacterial Activity of Carvacrol, Citral, and Geraniol against Salmonella typhimurium in Culture Medium and on Fish Cubes. J. Food Sci. 1995, 60, 1364-1368, https://doi.org/10.1111/j.1365-2621.1995.tb04592.x.

22. Donsì, F.; Annunziata, M.; Sessa, M.; Ferrari, G. Nanoencapsulation of essential oils to enhance their antimicrobial activity in foods. LWT - Food Science and Technology 2011, 44, 1908-1914, https://doi.org/10.1016/j.lwt.2011.03.003.

23. Rai, M.; Ingle, A. Role of nanotechnology in agriculture with special reference to management of insect pests. Appl. Microbiol. Biotechnol. 2012, 94, 287-293, https://doi.org/10.1007/s00253-012-3969-4.

24. Donsì, F.; Ferrari, G. Essential oil nanoemulsions as antimicrobial agents in food. J. Biotechnol. 2016, 233, 106-120, https://doi.org/10.1016/j.jbiotec.2016.07.005.

25. da Silva, A.C.R.; Ferro, J.A.; Reinach, F.C.; Farah, C.S.; Furlan, L.R.; Quaggio, R.B.; Monteiro-Vitorello, C.B.; Sluys, M.A.V.; Almeida, N.F.; Alves, L.M.C.; do Amaral, A.M.; Bertolini, M.C.; Camargo, L.E.A.; Camarotte, G.; Cannavan, F.; Cardozo, J.; Chambergo, F.; Ciapina, L.P.; Cicarelli, R.M.B.; Coutinho, L.L.; Cursino-Santos, J.R.; El-Dorry, H.; Faria, J.B.; Ferreira, A.J.S.; Ferreira, R.C.C.; Ferro, M.I.T.; Formighieri, E.F.; Franco, M.C.; Greggio, C.C.; Gruber, A.; Katsuyama, A.M.; Kishi, L.T.; Leite, R.P.; Lemos, E.G.M.; 
Lemos, M.V.F.; Locali, E.C.; Machado, M.A.; Madeira, A.M.B.N.; Martinez-Rossi, N.M.; Martins, E.C.; Meidanis, J.; Menck, C.F.M.; Miyaki, C.Y.; Moon, D.H.; Moreira, L.M.; Novo, M.T.M.; Okura, V.K.; Oliveira, M.C.; Oliveira, V.R.; Pereira, H.A.; Rossi, A.; Sena, J.A.D.; Silva, C.; de Souza, R.F.; Spinola, L.A.F.; Takita, M.A.; Tamura, R.E.; Teixeira, E.C.; Tezza, R.I.D.; Trindade dos Santos, M.; Truffi, D.; Tsai, S.M.; White, F.F.; Setubal, J.C.; Kitajima, J.P. Comparison of the genomes of two Xanthomonas pathogens with differing host specificities. Nature 2002, 417, 459-463, https://doi.org/10.1038/417459a.

26. Moreno, S.; Scheyer, T.; Romano, C.S.; Vojnov, A.A. Antioxidant and antimicrobial activities of rosemary extracts linked to their polyphenol composition. Free Radical Res. 2006, 40, 223-231, https://doi.org/10.1080/10715760500473834.

27. Cabrejos, D.A.L.; Alexandrino, A.V.; Pereira, C.M.; Mendonça, D.C.; Pereira, H.D.M.; Novo-Mansur, M.T.M.; Garratt, R.C.; Goto, L.S. Structural characterization of a pathogenicity-related superoxide dismutase codified by a probably essential gene in Xanthomonas citri subsp. citri. PLoS One 2019, 14, e0209988, https://doi.org/10.1371/journal.pone.0209988.

28. Moghimi, R.; Ghaderi, L.; Rafati, H.; Aliahmadi, A.; McClements, D.J. Superior antibacterial activity of nanoemulsion of Thymus daenensis essential oil against E. coli. Food Chem. 2016, 194, 410-415, https://doi.org/10.1016/j.foodchem.2015.07.139.

29. Otoni, C.G.; Moura, M.R.d.; Aouada, F.A.; Camilloto, G.P.; Cruz, R.S.; Lorevice, M.V.; Soares, N.d.F.F.; Mattoso, L.H.C. Antimicrobial and physical-mechanical properties of pectin/papaya puree/cinnamaldehyde nanoemulsion edible composite films. Food Hydrocolloids 2014, 41, 188-194, https://doi.org/10.1016/j.foodhyd.2014.04.013.

30. Jiang, Y.; Wu, N.; Fu, Y.-J.; Wang, W.; Luo, M.; Zhao, C.-J.; Zu, Y.-G.; Liu, X.-L. Chemical composition and antimicrobial activity of the essential oil of Rosemary. Environ. Toxicol. Pharmacol. 2011, 32, 63-68, https://doi.org/10.1016/j.etap.2011.03.011.

31. Fernandez, P.; André, V.; Rieger, J.; Kühnle, A. Nano-emulsion formation by emulsion phase inversion. Colloids Surf. Physicochem. Eng. Aspects 2004, 251, 53-58, https://doi.org/10.1016/j.colsurfa.2004.09.029.

32. Balta, I.; Brinzan, L.; Stratakos, A.C.; Linton, M.; Kelly, C.; Pinkerton, L.; Corcionivoschi, N. Geraniol and linalool loaded nanoemulsions and their antimicrobial activity. Bulletin UASVM Animal Science and Biotechnologies 2017, 74, 2, https://doi.org/10.15835/buasvmcn-asb:0025.

33. Pasquali, R.C.; Taurozzi, M.P.; Bregni, C. Some considerations about the hydrophilic-lipophilic balance system. Int. J. Pharm. 2008, 356, 44-51, https://doi.org/10.1016/j.ijpharm.2007.12.034.

34. Huang, Q.; Yu, H.; Ru, Q. Bioavailability and Delivery of Nutraceuticals Using Nanotechnology. J. Food Sci. 2010, 75, R50-R57, https://doi.org/10.1111/j.1750-3841.2009.01457.x.

35. Su, D.; Zhong, Q. Formation of thymol nanoemulsions with combinations of casein hydrolysates and sucrose stearate. J. Food Eng. 2016, 179, 1-10, https://doi.org/10.1016/j.jfoodeng.2016.01.030.

36. Hu, Q.; Gerhard, H.; Upadhyaya, I.; Venkitanarayanan, K.; Luo, Y. Antimicrobial eugenol nanoemulsion prepared by gum arabic and lecithin and evaluation of drying technologies. Int. J. Biol. Macromol. 2016, 87, 130-140, https://doi.org/10.1016/j.ijbiomac.2016.02.051.

37. Wang, L.; Zhang, Y. Eugenol Nanoemulsion Stabilized with Zein and Sodium Caseinate by Self-Assembly. J. Agric. Food Chem. 2017, 65, 2990-2998, https://doi.org/10.1021/acs.jafc.7b00194.

38. Liang, R.; Xu, S.; Shoemaker, C.F.; Li, Y.; Zhong, F.; Huang, Q. Physical and Antimicrobial Properties of Peppermint Oil Nanoemulsions. J. Agric. Food Chem. 2012, 60, 7548-7555, https://doi.org/10.1021/jf301129k.

39. Pongsumpun, P.; Iwamoto, S.; Siripatrawan, U. Response surface methodology for optimization of cinnamon essential oil nanoemulsion with improved stability and antifungal activity. Ultrason. Sonochem. 2020, 60, 104604, https://doi.org/10.1016/j.ultsonch.2019.05.021.

40. Nostro, A.; Roccaro, A.S.; Bisignano, G.; Marino, A.; Cannatelli, M.A.; Pizzimenti, F.C.; Cioni, P.L.; Procopio, F.; Blanco, A.R. Effects of oregano, carvacrol and thymol on Staphylococcus aureus and Staphylococcus epidermidis biofilms. 2007, 56, 519-523, https://doi.org/10.1099/jmm.0.46804-0.

41. Kotan, R.; Dadasoglu, F.; Kordali, S.; Cakır, A.; Dikbas, N.; Cakmakcı, R. Antibacterial activity of essential oils extracted from some medicinal plants, carvacrol and thymol on Xanthomonas axonopodis pv. vesicatoria (Doidge) Dye causes bacterial spot disease on pepper and tomato. Journal of Agricultural Technology 2007, 3, 299-306.

42. Güllüce, M.; Sökmen, M.; Daferera, D.; Ağar, G.; Özkan, H.; Kartal, N.; Polissiou, M.; Sökmen, A.; Şahin, F. In Vitro Antibacterial, Antifungal, and Antioxidant Activities of the Essential Oil and Methanol Extracts 
of Herbal Parts and Callus Cultures of Satureja hortensis L. J. Agric. Food Chem. 2003, 51, 3958-3965, https://doi.org/10.1021/jf0340308.

43. da Silva, R.S.; de Oliveira, M.M.G.; de Melo, J.O.; Blank, A.F.; Corrêa, C.B.; Scher, R.; Fernandes, R.P.M. Antimicrobial activity of Lippia gracilis essential oils on the plant pathogen Xanthomonas campestris pv. campestris and their effect on membrane integrity. Pestic. Biochem. Physiol. 2019, 160, 40-48, https://doi.org/10.1016/j.pestbp.2019.06.014.

44. Khoshbakht, T.; Karami, A.; Tahmasebi, A.; Maggi, F. The Variability of Thymol and Carvacrol Contents Reveals the Level of Antibacterial Activity of the Essential Oils from Different Accessions of Oliveria decumbens. Antibiotics 2020, 9, https://doi.org/10.3390/antibiotics9070409.

45. Zakaria Nabti, L.; Sahli, F.; Laouar, H.; Olowo-okere, A.; Nkuimi Wandjou, J.G.; Maggi, F. Chemical Composition and Antibacterial Activity of Essential Oils from the Algerian Endemic Origanum glandulosum Desf. against Multidrug-Resistant Uropathogenic E. coli Isolates. Antibiotics 2020, 9, https://doi.org/10.3390/antibiotics9010029.

46. Marchese, A.; Barbieri, R.; Coppo, E.; Orhan, I.E.; Daglia, M.; Nabavi, S.F.; Izadi, M.; Abdollahi, M.; Nabavi, S.M.; Ajami, M. Antimicrobial activity of eugenol and essential oils containing eugenol: A mechanistic viewpoint. Crit. Rev. Microbiol. 2017, 43, 668-689, https://doi.org/10.1080/1040841X.2017.1295225.

47. Sauer, A.V.; Santos, E.M.; Gonçalves-Zuliani, A.M.; Nocchi, P.T.; Nunes, W.M.; Bonato, C.M. Bacteriostatic and bactericidal activity in vitro of different essential oils as alternative treatments to control Xanthomonas citri subsp. citri. Acta Horticulturae 2015, 1065, 931-936, https://doi.org/10.17660/actahortic.2015.1065.116.

48. Mirzaei-Najafgholi, H.; Tarighi, S.; Golmohammadi, M.; Taheri, P. The Effect of Citrus Essential Oils and Their Constituents on Growth of Xanthomonas citri subsp. citri. Molecules 2017, 22, https://doi.org/10.3390/molecules22040591.

49. Mutlu-Ingok, A.; Firtin, B.; Karbancioglu-Guler, F.; Altay, F. A study on correlations between antimicrobial effects and diffusion coefficient, zeta potential and droplet size of essential oils. International Journal of Food Engineering 2020, 16, https://doi.org/10.1515/ijfe-2019-0354.

50. Buranasuksombat, U.; Kwon, Y.J.; Turner, M.; Bhandari, B. Influence of emulsion droplet size on antimicrobial properties. Food Sci. Biotechnol. 2011, 20, 793-800, https://doi.org/10.1007/s10068-011-0110$\mathrm{x}$.

51. Terjung, N.; Löffler, M.; Gibis, M.; Hinrichs, J.; Weiss, J. Influence of droplet size on the efficacy of oil-inwater emulsions loaded with phenolic antimicrobials. Food Funct. 2012, 3, 290-301, https://doi.org/10.1039/c2fo10198j.

52. Kumari, S.; Kumaraswamy, R.V.; Choudhary, R.C.; Sharma, S.S.; Pal, A.; Raliya, R.; Biswas, P.; Saharan, V. Thymol nanoemulsion exhibits potential antibacterial activity against bacterial pustule disease and growth promotory effect on soybean. Sci. Rep. 2018, 8, 6650, https://doi.org/10.1038/s41598-018-24871-5.

53. Jirovetz, L.; Buchbauer, G.; Bail, S.; Denkova, Z.; Slavchev, A.; Stoyanova, A.; Schmidt, E.; Geissler, M. Antimicrobial Activities of Essential Oils of Mint and Peppermint as Well as Some of Their Main Compounds. J. Essent. Oil Res. 2009, 21, 363-366, https://doi.org/10.1080/10412905.2009.9700193.

54. Zandonadi, F.S.; Ferreira, S.P.; Alexandrino, A.V.; Carnielli, C.M.; Artier, J.; Barcelos, M.P.; Nicolela, N.C.S.; Prieto, E.L.; Goto, L.S.; Belasque, J., Jr.; Novo-Mansur, M.T.M. Periplasm-enriched fractions from Xanthomonas citri subsp. citri type A and X. fuscans subsp. aurantifolii type B present distinct proteomic profiles under in vitro pathogenicity induction. PLoS One 2020, 15, e0243867, https://doi.org/10.1371/journal.pone.0243867.

55. Sarwar, A.; Katas, H.; Zin, N.M. Antibacterial effects of chitosan-tripolyphosphate nanoparticles: impact of particle size molecular weight. J. Nanopart. Res. 2014, 16, 2517, https://doi.org/10.1007/s11051-014-25179.

56. Bajpai, V.K.; Dung, N.T.; Suh, H.-J.; Kang, S.C. Antibacterial Activity of Essential Oil and Extracts of Cleistocalyx operculatus Buds Against the Bacteria of Xanthomonas spp. J. Am. Oil Chem. Soc. 2010, 87, 1341-1349, https://doi.org/10.1007/s11746-010-1623-9.

57. Silva, M.T.N.; Ushimaru, P.I.; Barbosa, L.N.; Cunha, M.; Fernandes Junior, A. Antibacterial activity of plant essential oils against Staphylococcus aureus and Escherichia coli strains isolated from human specimens. Revista Brasileira de Plantas Medicinais 2009, 11, 257-262, https://doi.org/10.1590/S151605722009000300005. 